\section{Epigraphy: The Palaeohispanic Languages}

\author{
Alejandro G. Sinner ${ }^{1}$ and Javier Velaza Frías ${ }^{2}$ \\ ${ }^{1}$ Department of Greek and Roman Studies, \\ University of Victoria, Victoria, BC, Canada \\ ${ }^{2}$ Faculty of Philology, Universitat de Barcelona, \\ Barcelona, Catalonia, Spain
}

\section{Introduction}

At least four writing systems, in addition to the Phoenician, Greek, and Latin ones, were used between the fifth century BCE and the first century $\mathrm{CE}$ to write the indigenous languages of the Iberian Peninsula (collectively known as the Palaeohispanic languages): Tartessian, Iberian, Celtiberian, and Lusitanian. In total over 3000 inscriptions are preserved in what is certainly the largest corpus of epigraphic expression in the western Mediterranean world with the exception of the Italian peninsula.

Our knowledge of these languages remains unequal. In some cases, as with Tartessian, the writing system is not yet decoded, which makes it impossible to determine the linguistic family to which it belongs. In other cases, our knowledge of the writing system is much greater - as with Celtiberian - or even total, as in the case of Lusitanian, a language that uses the Latin alphabet, and, since the language belongs to a Celtic branch of Indo-European, it can be studied with the tools and techniques of comparative linguistics. Iberian stands somewhere between these two extremes. As a language, it is non-Indo-European and typologically agglutinative (for Indo-European and non-Indo-European languages in Hispania, see Villar 2000). Our knowledge of Iberian has increased substantially in recent years, but the language still remains largely undeciphered. To all this should be added the fact that, for an extensive part of the Iberian Peninsula, there is no other evidence than the place- and personal-name elements recorded in indirect sources. Described in this way, the situation might appear disappointing. Yet, in the last few decades, there have been modest but unquestionable advances that enable us to understand somewhat better the uses to which writing was put among the different peoples inhabiting the pre-Roman Iberian Peninsula.

The study and understanding of these languages is essential to achieve a better appreciation of the social, economic, and cultural history of Hispania and the ancient western Mediterranean. They are also key to our comprehension of colonial Phoenician and Greek literacy, which lies at the root of the spread of these languages, and also of the diffusion of Roman literacy, which played an important role in the final expansion of what are known as the Palaeohispanic languages. 


\section{Definition}

Strictly speaking, the Palaeohispanic languages were those spoken between the fifth century $\mathrm{BCE}$ and the first century $\mathrm{CE}$ in what today are the territories of Spain and Portugal. In the widest sense, however, Phoenician and Greek should also be included among the Palaeohispanic languages, as they were spoken by colonists born in Hispania between the ninth and sixth centuries BCE. Therefore, no fewer than six varieties of epichoric signaries and several adaptations of the Greek and Latin alphabets make up the complex mosaic of scripts and languages recorded in the Iberian Peninsula. In standard usage, however, the term is only applied to the languages that were not spoken outside Hispania, an area in southern France that extends from the River Hérault toward the west - culturally inseparable from Spain in Antiquity and where the northeastern Iberian script is predominant - being included for practical and historical reasons as part of this definition. It is important to bear in mind that there is no absolute correspondence between the Palaeohispanic languages and the scripts that these languages used over time, since the latter originated in the Iberian Peninsula itself although in response to external stimuli.

Today, when we speak of Palaeohispanic studies, most scholars understand or refer to the study of the languages and writing systems used in ancient Hispania prior to the generalization of Latin. Therefore, this is a well-established academic field in which several disciplines play a fundamental role; the subject deals with a complex range of cultural contexts covering an extensive geographical area as well as a huge chronological scope, almost a millennium of history. Despite that, the academic field of Palaeohispanic studies is a recent one, and it is convenient to have some idea of its development as a discipline if we aim to understand what Palaeohispanic studies really are.

\section{Historical Background}

Even though the field of Palaeohispanic studies is a discipline that has developed relatively recently, it nevertheless can trace its origins and roots back to the Renaissance. Two main lines of research have contributed to creating the modern field of Palaeohispanic studies. On the one hand, humanists and numismatists have long been concerned with and interested in collecting and cataloguing ancient coins. In Spain, however, some of these coins were written in an incomprehensible script and swiftly provoked great interest (for the coins using Palaeohispanic languages, see Ripollès and Sinner 2019). As a consequence, a line of research that aimed to decipher these coin legends started to develop. On the other hand, classicists interested in the study of Greek and Latin texts as well as Latin epigraphy aimed to achieve a greater understanding of and to reconstruct the ancient history of Hispania. To do so, they retrieved substantial amounts of information concerning different peoples and cultures, including in many cases native onomastics and linguistic information (De Hoz 2019 with bibliography).

From the sixteenth century onward, when Antonio Agustín first identified some syllabograms, but especially during the eighteenth and nineteenth centuries, when numismatists catalogued, translated, and tried to assign values to those incomprehensible signs, a greater understanding of the script was increasingly sought. During this long process, both pioneering scientific ideas that had never been applied to the subject before - such as the importance of a Celtic stratum in the linguistic panorama of Hispania and also highly speculative theories, in many cases unfounded, such as the Vasco-Iberian theory, a belief in the linguistic unity of ancient preRoman Spain, where a language that was the ancestor of modern-day Basque was thought to have been spoken, were developed; these were extremely influential both inside and outside Spain. 
It was not until 1920 that there was a noticeable change in the situation thanks to the contributions of Gómez-Moreno. He first conceived and fully developed the idea of a semi-syllabic script in which the representation of stop consonants was always accompanied by a vowel $(<\mathrm{da}>,<\mathrm{de}>$, $<$ di $>,<$ do $>,<$ du $>$, etc.). This was a groundbreaking thesis and led to the relationship long desired by Spanish numismatists between the coin legends written in Iberian script and their equivalent Latin forms being established. For most scholars, Gómez-Moreno's work marked the beginning of modern Palaeohispanic studies since, after his decipherment of the alphabet, it was possible to distinguish more than one language (Iberian and Celtiberian) in the epigraphic corpus.

Initially the field of Palaeohispanic studies was a regional field of limited impact outside the Iberian Peninsula. It was only thanks to A. Tovar's linguistic works and J. Untermann's epigraphic corpus (1975-2001) that Palaeohispanic studies truly started to flourish. Unfortunately, Untermann's death prevented the publication of his Supplementa, including all the recently appeared inscriptions. All these data are now collected, including those in $M L H$, in the Hesperia database (BDHesp), which is an ongoing project and certainly one of the future pillars for Palaeohispanic studies.

\section{Key Issues/Current Debates}

In the field of Palaeohispanic studies, there are currently many unresolved debates, and positions are sometimes remarkably disparate. For this reason, in the following lines we have tried to be meticulous when expounding the state of the question in each area of study. The aim is to make clear the difference between those hypotheses that can count on broad acceptance and those that are still currently under evaluation and debate.

\section{The Earliest Indications of Epigraphy}

Writing is not a locally born phenomenon in the Iberian Peninsula, but rather it is closely linked to the presence of Phoenician and Greek epigraphic cultures (for a linguistic history of the Iberian Peninsula in antiquity, see De Hoz 2010, 2011). Both groups introduced certain uses of writing through their colonial settlements, uses that served as a stimulus and in many cases as models for the native populations. Bearing this in mind, it is not surprising that the first manifestations of writing in the Iberian Peninsula occurred precisely around those places where Greeks and Phoenicians had a more stable presence. As early as the late eighth century $\mathrm{BCE}$ (or perhaps the early seventh century BCE), the impact of Greek and Phoenician culture can be demonstrated in southern Andalusia by the finding of scratched graffiti on pottery vessels in both languages (Zamora 2019 with bibliography). Actually, it is the coexistence of these two scripts that seems to have created a suitable background for the birth of the first epichoric script to be recorded in Iberia. The scarcity of recorded examples, however, does not affect its significance, which lies in the fact that all the other Palaeohispanic scripts that were used in the Iberian Peninsula were derived from this initial script (Ferrer and Moncunill 2019). Most of its signs are morphologically similar to those of the Phoenician alphabet. In addition to that, in the two inscriptions reproducing a complete or incomplete signary (Espanca and Villasviejas del Tamuja), the order of the first signs coincides exactly with those of the Phoenician alphabet, thus proving that the latter was the model used for the elaboration of the first Palaeohispanic writing system. In all probability, this early writing system was not conceived to scratch the few modest graffiti on pottery sherds that have come down to us; its main use should be related to the intense trading activity that is well documented in this region. Nevertheless, due to the limitations of our current sample, any hypothesis formulated cannot be considered other than mere speculation.

\section{Epigraphy in the Southwest}

A region in the Algarve (Portugal) adapted the early Palaeohispanic script during the seventh century BCE. About a hundred inscriptions on stone, probably funerary steles (Fig. 1), have been discovered in this area. Most of them are undecorated, but a few show a schematic figure, 


\section{Epigraphy: The Palaeohispanic Languages, Fig. 1 The stele from Mesas do Castelinho. (Photograph: A. Guerra)}
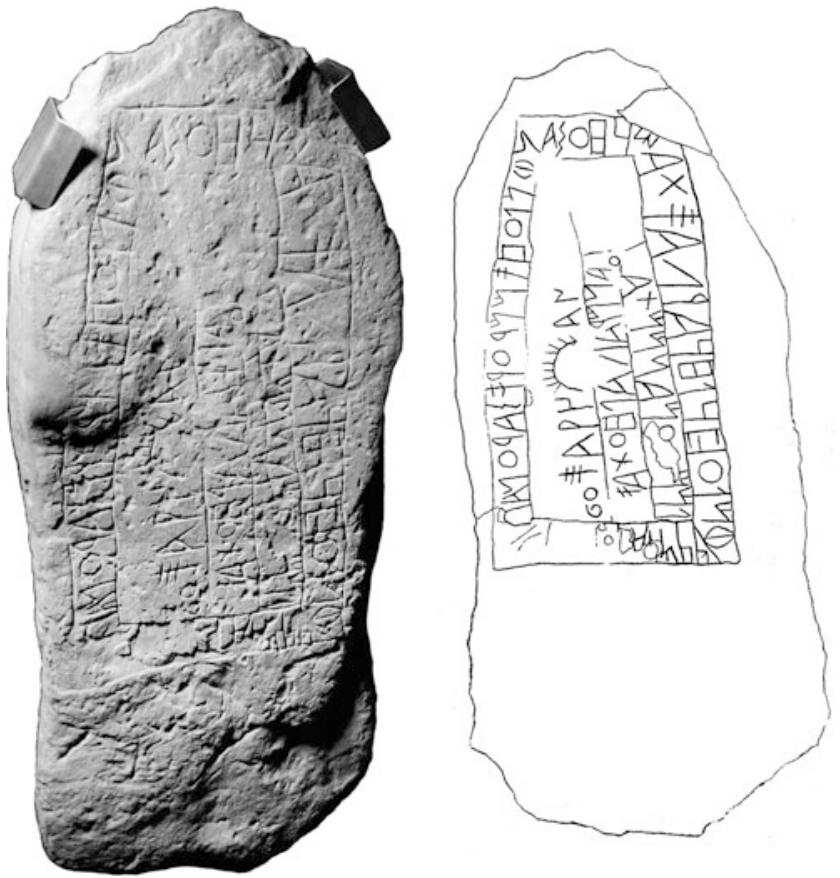

possibly a heroic warrior. These monuments may belong to a tradition of Bronze Age origin of which ample proof has been found in Alentejo and Extremadura. Recently found Phoenician steles from Lisbon datable to the eighth century BCE could also have been used as models. Apart from the steles, only some graffiti, probably personal names, on pottery vessels are known. The possibility of attributing a votive function to the signary from Villasviejas de Tamuja, recently reinterpreted as an ostrakon, cannot be discarded.

The majority of the texts are written from right to left, at times adopting a spiral layout following the edges of the pottery sherd. This writing is known as the southwestern, south Lusitanian, or Tartessian script (Correa and Guerra 2019 with bibliography). It is a semi-syllabary in which each vowel and continuous consonant is attributed a graphic symbol, as in alphabets, with stop consonants being indicated in a syllabic form, as in syllabaries. This characteristic was to become a shared property of all Palaeohispanic writing systems, an especially relevant aspect when it is taken into account that the main model for the script's creation was the Phoenician alphabet. In addition, the southwestern system has another specific characteristic: each stop syllabogram is followed by a vowel for the same sound, $t a^{a}, t e^{e}, t i^{i}$, etc., an unnecessary procedure, redundancy, normally accepted as proof that the script had indeed not been created for writing the language in question. Regrettably, the degree of decipherment is not as advanced as might be desirable. At present, there is no consensus among specialists regarding the value of many signs. In addition, most texts are written in scriptio continua, with the resulting difficulty in dividing the texts into words. Therefore, the southwestern language remains undeciphered. The proposal that this southwestern language should be considered a Celtic language has not been accepted among specialists, who are mostly still skeptical about its typology and possible relationships. In chronological terms, the dating of the southwestern inscriptions is very complex, especially since a great number of steles have been found in reused contexts. Despite these difficulties, most scholars would agree that this particular outburst of inscription production and its disappearance may have taken place in the second half of the seventh century BCE, and no subsequent written culture has been found in the area. The next inscriptions to be engraved were 
Roman and must be dated to the late republican period.

\section{Iberian Epigraphy}

The Iberian language (Moncunill and Velaza 2017; Velaza 2019 with bibliography) is doubtless the best attested among all the Palaeohispanic languages. More than 2200 inscriptions can be located in a wide geographical area between Roussillon (France), coexisting there with the Gallic language, and Andalusia. Its chronological framework covers from the fifth century $\mathrm{BCE}$ until a moment of time after the reign of Augustus. The acquisition of writing by the Iberians can be considered a consequence of their contact with the Greek colonies in southern France and northeastern Spain. The earliest securely dated examples are graffiti on Attic pottery found in the excavations carried out at the oppidum of Ullastret (Girona). From this same period, inscriptions have also been found on lead tablets (Fig. 2), similar to those from Pech Maho or Ampurias, and in which Iberian names appear as participants in trade transactions. Nevertheless, the Iberian language remains essentially undeciphered, a handicap that makes it difficult to achieve a good understanding of these texts. Despite this problem, the Iberian lead tablets of this initial period basically seem to contain texts related to commercial activities and the distribution of goods. Stamps on dolia or amphorae can also be found, proving the use of epigraphy in productive activities. In short, the earlier Iberian inscriptions, between fifth and third centuries BCE, can mainly be categorized as colonial epigraphy. There were still no funerary inscriptions in this period. The cemeteries known exhibit iconographic forms of ancient tradition or oriental influence (via southern Spain) and, more than anything else, funerary steles without inscriptions (Ensérune). By the middle of the third century, the introduction of the epigraphic habit seems to have been extended into the religious sphere. The use of writing is gradually adopted in the rock-face sanctuaries in Cerdanya (Campmajó and Ferrer 2010), and writing seems to be an important aspect of ritual with the signary as a votive element. Painted Iberian pottery was produced around the same time, in which ritual was mixed with ethnic and elite selfrepresentation, and writing played a leading role. During the second century BCE, a far-reaching change occurred in Iberian epigraphic culture as a consequence of the Roman presence. With the influence of Roman public writing models, new categories of epigraphy and inscriptions on different materials appear, as well as the development of carving techniques and the use of new palaeographic forms and formulae. At this moment tomb inscriptions started to be engraved. In the first instance, the epigraphic language coexisted with the iconographic language, subsequently giving way to a gradual disappearance of
Epigraphy: The Palaeohispanic Languages, Fig. 2 Lead sheet from Tivissa. (Photograph: D. Asensio)

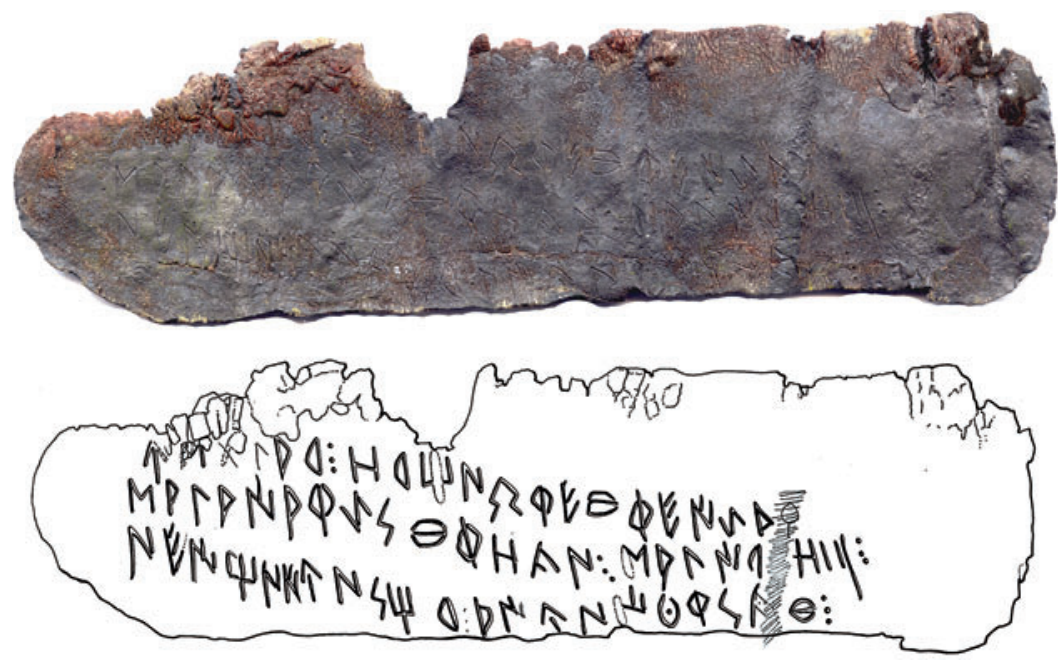


decoration in favor of textual predominance. Votive inscriptions mainly associated with rock faces became sanctuary epigraphy at a time when sacred spaces were monumentalized. Perhaps the best example of these practices can be seen at the sanctuary of Liber Pater in Muntanya Frontera. A form of Iberian epigraphy that can be described as public emerged. Some inscriptions interpreted as honorific or monumental appear at this moment, especially in the forum or public buildings, as in Emporiae, Tarraco or Saguntum, showing the clear influence of contemporary Roman epigraphic habits. In the ambit of public and civic epigraphy, mention must be made of Iberian coin inscriptions. While the earliest examples can be dated to the end of the third century $\mathrm{BCE}$, the peak of the phenomenon took place in the second century BCE and lasted until well into the first century BCE. In the same way, in some specific places like Saguntum, the continued use of Iberian writing into the imperial period must have arisen from a desire to maintain the features of an ancient epigraphic tradition as part of a civic or elite identity. To summarize, the history of Iberian written culture, from a diachronic perspective, can be understood as a process of expansion that starts with colonial epigraphy in the fifth-third centuries BCE and develops into a more extended written culture, with extensive public and private use of writing in the second-first centuries BCE. The enormous quantity and variety of materials that were inscribed, as well as the broad time span for which evidence is available, suggest a more socially widespread use of writing than scholars are often willing to accept. The fact that several writing systems were used to write the Iberian language seems to reinforce this conclusion. The northeastern semi-syllabary and the southeastern script (Ferrer and Moncunill 2019) are derived from or descendants of the ancient Palaeohispanic script, but they suppose a new adaptation with special features. What is known as the GrecoIberian script is indeed an alphabet adapted around the fourth century BCE from Ionic Greek. In fact, Greek and Latin characters were also used to write texts in Iberian, but to a far lesser extent. Such a wide variety of graphic systems seems to reflect a plurality of needs and writing traditions rather than the supposedly limited literacy usually attributed to the Iberian world, where in many cases writing has been restricted to an elite.

\section{Celtiberian Epigraphy}

As ancient historians clearly state, the Celtiberians were peoples composed by different tribal groupings, such as the Arevaci, Lusones, Belli, and Titii, that inhabited an area of the central Meseta and the Ebro valley. The language they spoke and wrote, however, was a variety of Peninsular Celtic, also shared by other neighboring peoples, for instance, the Berones and Carpetani. Therefore, when Celtiberian epigraphy is mentioned, reference is not being made to the tribal name or ethnic grouping, but to broader linguistic criteria (Beltrán and Jordán 2016, 2019). Despite being a geographical neighbor of the Iberian culture and obviously interrelated with it in many aspects, Celtiberian epigraphy displays a very different character, function, and development when compared with the former. A quick look at a chart comparing Iberian and Celtiberian epigraphy (Fig. 3) allows us to appreciate the quantitative differences that exist between them, which doubtlessly reflect the gap in territorial distribution and chronological time span. In addition to that, differences regarding the penetration of literacy and, especially, a significant divergence as concerns the most commonly used material supports and epigraphic functions can also be detected. As mentioned above, in the Iberian sphere, there are many inscriptions on lead plaques and tablets, often reflecting commercial transactions or curses, but in the Celtiberian area we only know one single letter on lead, which comes from a site located in the epigraphic frontier region with the Iberian epigraphic area. While the Iberians made little use of bronze as a material support, in contrast the Celtiberians made much greater use of it and in different contexts. How and why the Celtiberians adopted writing is a question that remains unanswered. Only a few years ago, scholars would have agreed that this process took place as a consequence of the Roman arrival in the Peninsula. Recent research, however, together with our current knowledge of the scripts, 


\section{Epigraphy: The Palaeohispanic} Languages, Fig. 3 Chart comparing Iberian and Celtiberian epigraphy

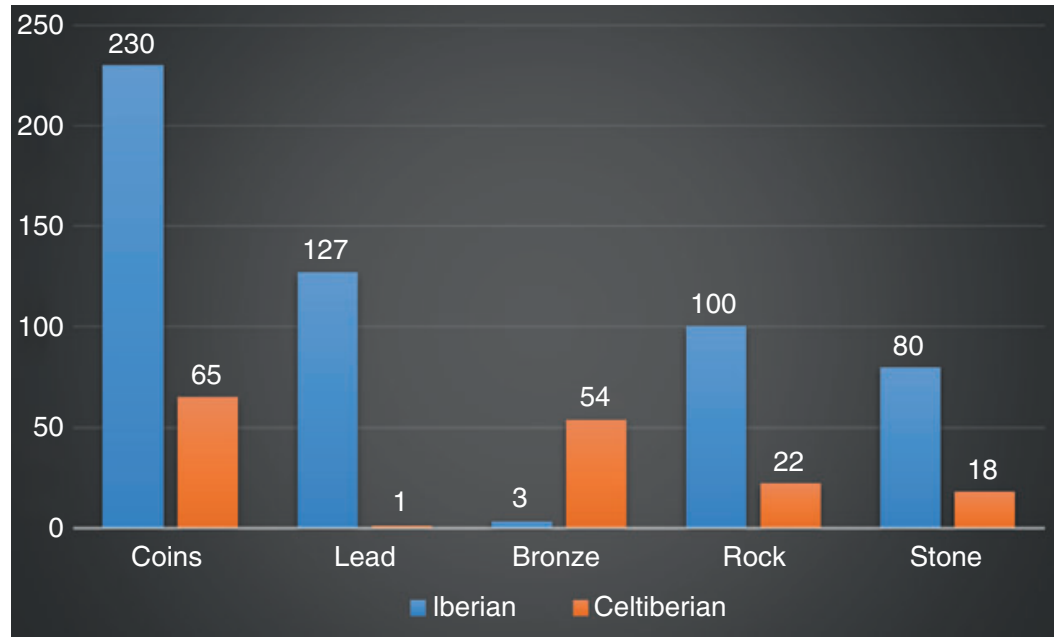

encourages us to think that the Celtiberians most probably started writing before that date, although perhaps not long before. Therefore, around the mid-third century BCE, the Celtiberians adapted two variants of the Iberian script in order to write their language, a practice that lasted until about the change of the era. From the first century CE on, Latin characters were introduced into the Celtiberian writing system with a few small adaptations, for example, the adding of an extra stroke to the $\mathrm{S}$, indicating the second sibilant in Celtiberian. This procedure cannot be understood as a localized palaeographic feature since it is documented in both the rock face and bronze inscriptions. With the currently available evidence, it is possible to say that the Celtiberian epigraphic culture was largely inspired by Roman inscriptions (Beltrán and Jordán 2008). This phenomenon is particularly obvious for the more than 30 tesserae hospitales on bronze, which exhibit numerous parallels with comparable Latin examples. Their morphology is diverse, but they can basically be classified in three groups: the hand-shaped ones, those in the form of animals, and those of geometrical shape. The bronze plaques are also of clear Roman influence. Some are medium-sized, but there are also others of much larger sizes, like the large bronze plaques from Botorrita (Fig. 4), for which there are Latin parallels from the same site. Our current knowledge of the Celtiberian language is fragmentary and therefore too poor to fully understand these large inscriptions. In many cases, it is difficult for scholars to agree on basic aspects of the text, such as the type of message they contain. Despite all these difficulties, in some cases we have quite reliable indications that their contents were of juridical nature and that they were probably issued by municipal authorities. This would be a shared characteristic between the bronze plaques and coin issues, another epigraphic category among the Celtiberians with no less than 47 known mints. Beside these categories of inscriptions, the Celtiberians seem to have used others as well. Funerary epigraphy is little represented in the corpus, perhaps due to its merely sporadic use although it is documented in some of the steles of local tradition found in cities like Clunia. Surely the reason why votive or religious epigraphy, beyond the scratched graffiti in the rock face sanctuaries like Peñalba de Villastar, failed to develop was the lack of monumental cult spaces in the Celtiberian world until well into the Roman period. Chronologically speaking, Celtiberian texts were written in Latin characters at Peñalba de Villastar at a time that was contemporary with or slightly earlier than Virgil's verses, in what we should perhaps consider to have been the final expression of the native epigraphy of Celtiberia. 

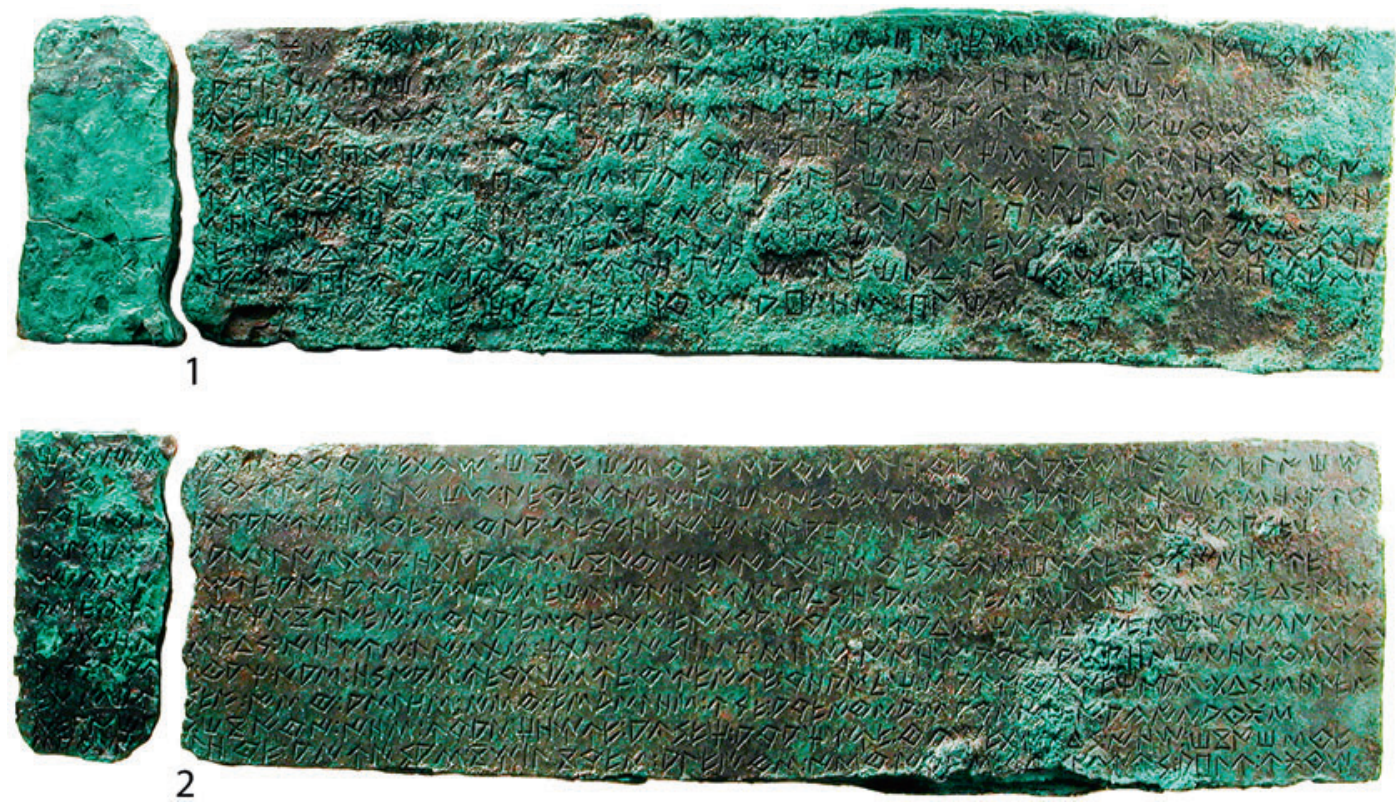

Epigraphy: The Palaeohispanic Languages, Fig. 4 First bronze from Contrebia Belaisca (Botorrita, Zaragoza). (Photograph: Museo de Zaragoza)

\section{Epigraphy: The Palaeohispanic Languages,}

Fig. 5 Lusitanian inscription from Arronches, Assunçâo

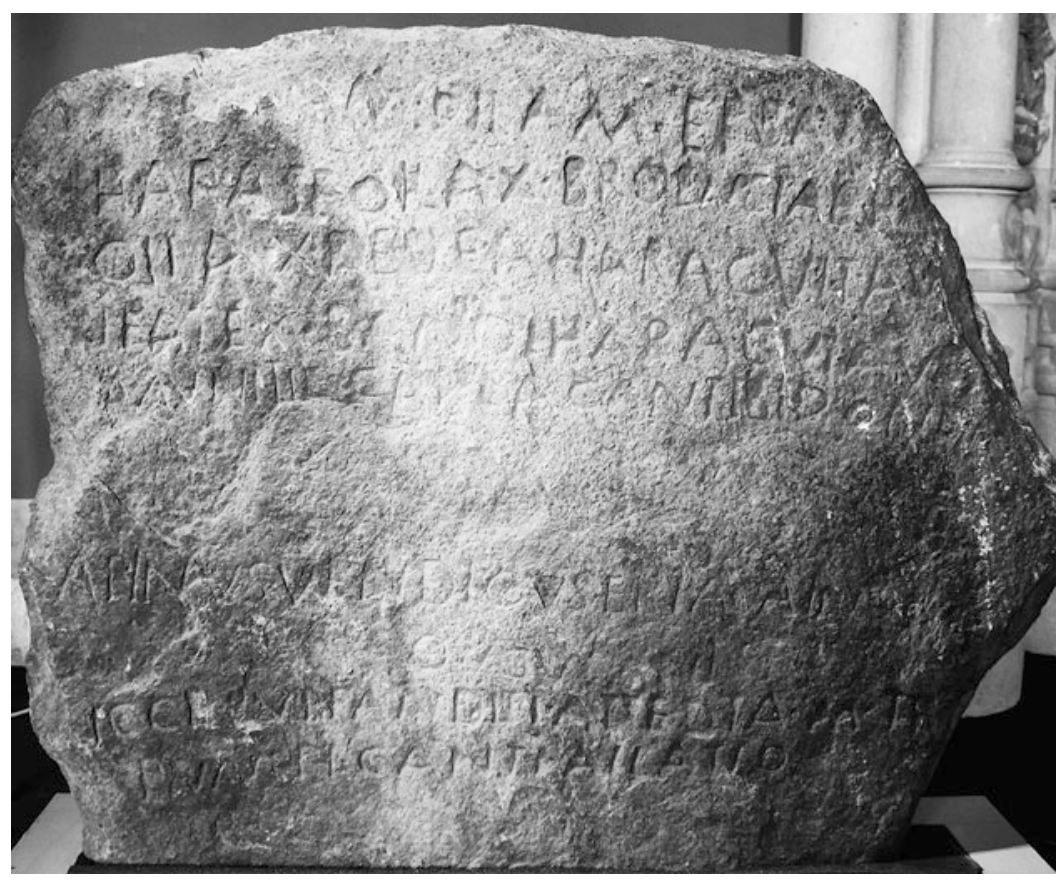

\section{Lusitanian Epigraphy}

The Lusitanian epigraphic corpus is composed of a total of six, possibly seven, inscriptions in Latin characters (Fig. 5) (Luján 2019 with bibliography), distributed in a small area in modern-day Portugal and Extremadura. It seems clear, however, that the linguistic territory where the Lusitanian language was used was much 
larger than the area suggested by these six inscriptions and should be extended to the rest of the Roman province of Lusitania and perhaps to part of Gallaecia, as indicated by the frequency of personal names and theonyms in Roman inscriptions (Vallejo 2016). The inscriptions in this limited corpus share certain common features. All use Latin characters, without introducing variations to fit the particular features of the language. All the texts are of religious content, related, as far as we are able to understand them, to rituals (involving animals) dedicated to certain gods. Furthermore, two of the inscriptions share another particular feature: the Lusitanian part of the text is headed by two brief sentences in Latin. These phrases indicate who the authors of the inscriptions were by using the formula Ambatus scripsi and Rufus et Tiro scripserunt. In short, all of them reflect the wish to monumentalize a rock-face sanctuary and therefore may be, to a certain extent, considered official epigraphic documents. The absolute lack of other inscriptions in Lusitanian would point toward a very limited epigraphic phenomenon, if it were not for the dating of the inscriptions. Traditionally, scholars have dated this corpus to the first and even second century CE. The appearance of the inscriptions from Arronches and Arroyo de la Luz III, however, introduced an additional palaeographic variable that could change this chronology: the archaic form of the $\mathrm{P}$ and linguistic arguments. The panorama of Lusitanian epigraphic culture would become more complicated if these inscriptions really should be dated to the republican period. If this were the case, the six inscriptions, despite being homogeneous in form and content, would nevertheless be spread over the time span of two centuries or more. Perhaps palaeography cannot be our only argument in this case, as we might be facing the survival of an alphabet with archaizing features. With all the evidence currently available, the most feasible scenario is one in which the Lusitanians did not record their language in a written form prior to the Roman period. Therefore, the Lusitanians never developed a true epigraphic culture, not even as a consequence of the implantation of Latin epigraphic models. The written form was used for texts only on an occasional basis, and within a ritual context. Whether the texts were in some way stereotyped before being carved and whether all of them belonged to a limited time span or were spread out in time are aspects that will still have to be elucidated in the future.

\section{Vascon Epigraphy?}

The Vascones were a group of peoples who, based on what is known from the ancient sources and the archaeological record, inhabited the modern territories of Navarre with some inroads into modern La Rioja (Calagorri, Graccurri) and Aragón (Segia, Iaca). Until a few years ago, the Vascones were considered to be an anepigraphic culture (for the territories of Hispania without epigraphy, see Gorrochategui and Vallejo 2019). However, today the situation is slightly different, and some of their cities are known to have issued coinage with legends in a script that is undoubtedly related to the Iberian script but which includes a particular set of graphic elements that can set this script apart. Some of these signs are completely unknown in any other Palaeohispanic script, mostly perhaps being imitations of Latin characters, and others are only rarely documented in the Iberian script. In general, these texts are exclusively known thanks to the survival of a small number of coins, which does not mean that some of these issues were not substantial or significant at their time (as is shown by the fact that imitations from Belgic Gaul are known). In addition to the public and civic nature of these epigraphic documents, other finds can help us to contemplate a more widespread use of writing among the Vascones: the most important of all is the inscription on the opus signinum pavement from Andelo. Although there is some controversy around this particular document - some scholars consider the text to be written using the Iberian language there is a degree of consensus that the text uses the Celtiberian script to write what could be an ancient form of Basque, the vernacular language in the region (for ancient languages in the Pyrenees, see Gorrochategui 1995 with bibliography). In addition to this extraordinary document, a new inscription engraved on stone from Olite and some graffiti using the Palaeohispanic script recovered in the territory of modern Pamplona 
should be added, completing what today is a very small corpus of inscriptions. Based on all this evidence, it seems obvious the Vascones undertook, around the mid-second century BCE, some writing experiments. To do so, sometimes they used the Celtiberian script, while on other occasions they adapted the Iberian one. It seems clear, however, that as in the case of the Lusitanians, they never developed a true epigraphic culture. An interesting difference between the Vascones and other groups discussed in this text (such as the Celtiberians) is that the former seem to have suffered "truncated epigraphization" as a consequence of Roman cultural influence. Such a phenomenon shows that in some cases Roman influence could stimulate local epigraphic habits, as in the case of the Celtiberians, while in others, the generalized use of Latin was able to eradicate early forms of local epigraphic expressions, as happened with the Vascones.

\section{Conclusions}

Maps can accurately synthesize the evolution of writing in the Iberian Peninsula between the fifth and the first centuries BCE. Inscriptions prior to the fourth century BCE follow a very clear pattern distributed in a coastal strip defined by the leading Greek and Phoenician colonies and their limited areas of influence. This pattern can be completed by the addition of the few southwestern inscriptions, which can be traced along the Rivers Guadiana and Guadalquivir (Fig. 6). A very different scenario can be presented by looking at a map including inscriptions from the fourth and third centuries BCE. Here, the southwestern inscriptions disappear, and epigraphic evidence does not reappear until the Roman imperial period (Fig. 7). In contrast, inscriptions in the coastal Mediterranean territories increase in number and show a progressive penetration inland following the River Ebro. A map focusing on inscriptions dated between the second and first centuries

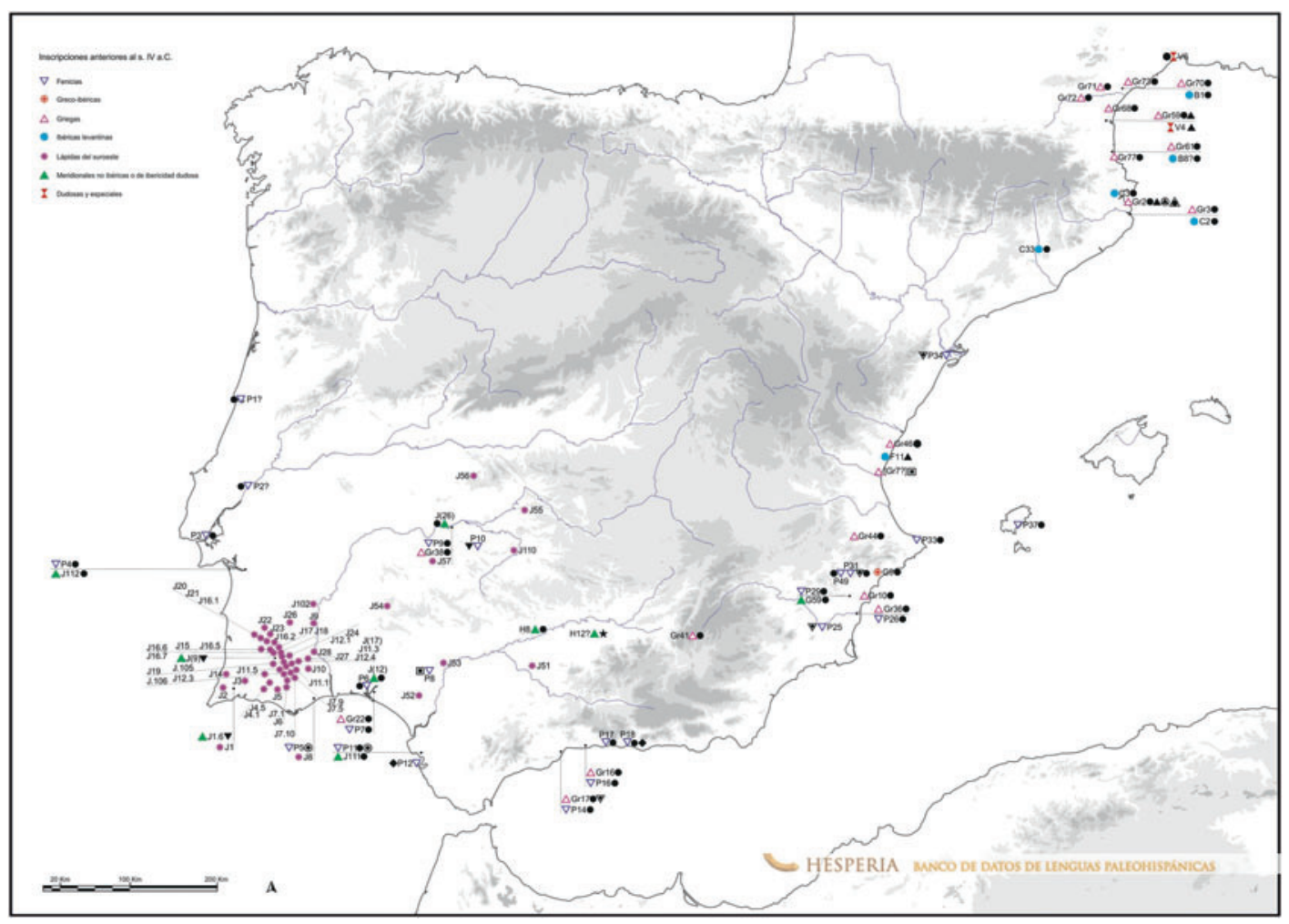

Epigraphy: The Palaeohispanic Languages, Fig. 6 Map including Palaeohispanic inscriptions prior to the fourth century BCE 


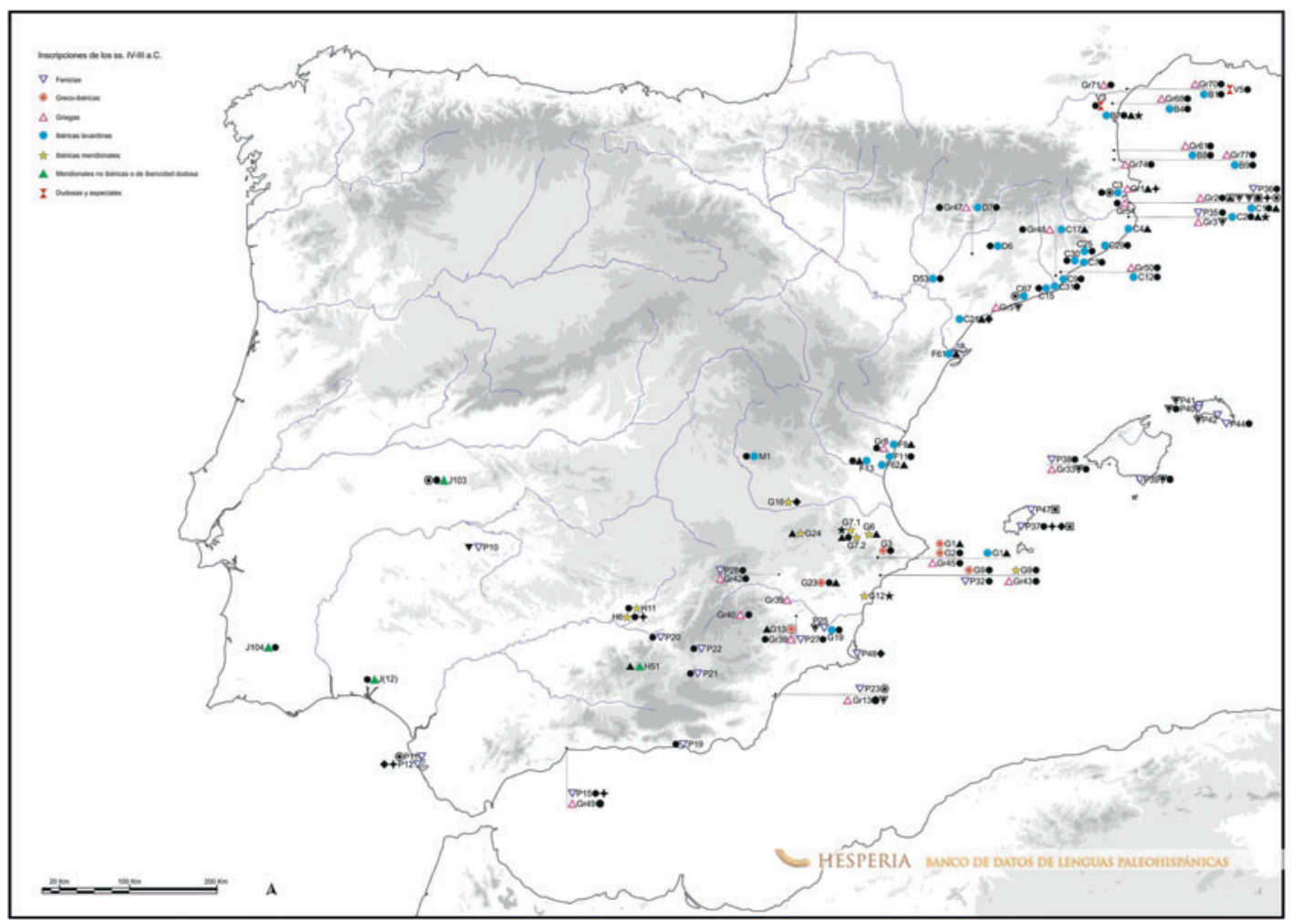

Epigraphy: The Palaeohispanic Languages, Fig. 7 Map including Palaeohispanic inscriptions from the fourth and third centuries BCE

BCE - including republican inscription using Latin - (Fig. 8) will immediately be characterized by the density of material in the territories along the Ebro valley and in the modern area of Andalusia. The opposite picture comes from the northwestern quarter of the peninsula, which remains anepigraphic, and its central areas, where the density is still quite low (for the relation between writing and colonization, see Díaz Ariño et al. 2019). This situation, which preludes the disappearance of the native epigraphic cultures to the advantage of Latin, arose around the end of the first century BCE and in the early first century $\mathrm{CE}$, the few Iberian inscriptions after this date being considered residual phenomena.

\section{Future Directions}

It is difficult to foresee the future directions of a field that depends heavily on uncovering new finds. That said, it is feasible that, as has happened in the last few decades, the lines of research will follow three fundamental directions:

1. The first of these research lines should move toward the consolidation of knowledge of the graphic systems used to write the Palaeohispanic languages. The studies conducted over the last years have renewed this area considerably, demonstrating that there are a greater variety of systems, or subsystems, of writing than was traditionally thought. Nevertheless, there is no consensus among scholars about how many systems existed and how some of their signs should be transcribed.

2. The second line should focus on the detailed study of each of the aforementioned epigraphic corpus, paying special attention to the methodological particularities that each of them imposes. In the case of the Indo-European 


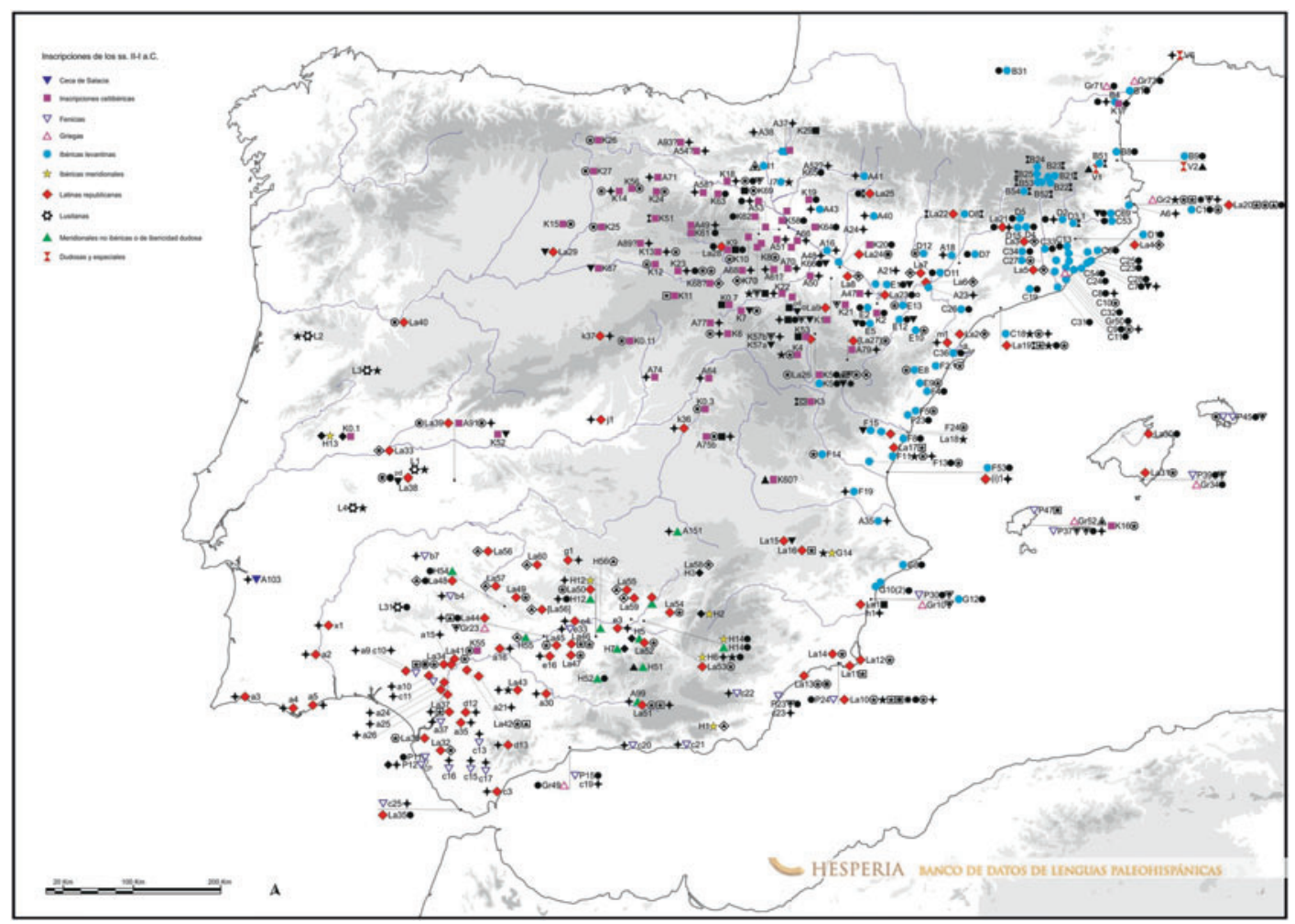

Epigraphy: The Palaeohispanic Languages, Fig. 8 Map including Palaeohispanic and Latin inscriptions from the second and first centuries BCE

languages, Celtiberian and Lusitanian, it is necessary to fine-tune the tools of analysis provided by comparative linguistics through the intensification of the internal analysis of the texts and the contribution of external epigraphic parallels. In the case of the nonIndo-European languages, Tartessian and Iberian, the combinatory analysis established by Untermann could be challenged in the future as the most suitable method to approach these languages, thanks to the use of new tools facilitated by innovatory techniques such as segmentation and frequency analysis, but also by the application of paradigms from linguistic typology. In both cases, however, it is fundamental to have an up-to-date open-access epigraphic corpus that is soon going to be available for the first time thanks to the Hesperia project (BDHesp). Finally, in the case of the languages for which there is very limited evidence, such as proto-Basque, or in the case of those only attested by onomastics, our reliance on new finds is even more pronounced.

3. The last of the three research lines must be concerned with promoting further in-depth comparative studies between the different Palaeohispanic epigraphic cultures. It is necessary to extend this type of studies into a broader field such as the pre-Roman epigraphies in the ancient Mediterranean. To do so, the AELAW project (Ancient European Languages and Writings) is currently working on a data bank for the ancient languages and epigraphies in the Mediterranean area that will undoubtedly become the point of reference for multiple future studies. 


\section{Cross-References}

Epigraphy, Greek

- Epigraphy, Imperial Latin

- Epigraphy, Latin: Early Through Late Republican

\section{References}

Beltrán, F. and Jordán, C. 2008. La epigrafía pública celtibérica. In Las culturas del Próximo Oriente Antiguo y su expansión mediterránea. eds. J.J. Justel, J.P. Vita and J.A. Zamora. Zaragoza: 289-320.

Beltrán, F., and C. Jordán. 2016. Celtibérico. Lengua. Escritura. Epigrafía. Zaragoza: Prensas de la Universidad de Zaragoza.

Beltrán, F., and C. Jordán. 2019. Writing and language in Celtiberia. In Palaeohispanic languages and epigraphies, ed. A.G. Sinner and J. Velaza. Oxford: Oxford University Press.

Campmajó, P., and J. Ferrer. 2010. Le nouveau corpus d'inscriptions ibériques rupestres de la Cerdagne 1: premiers résultats. Palaeohispanica 10: 249-274.

Correa, J.A., and A. Guerra. 2019. The linguistic situation in the South-West of the Iberian Peninsula. In Palaeohispanic languages and epigraphies, ed. A.G. Sinner and J. Velaza. Oxford: Oxford University Press.

De Hoz, J. 2010. Historia lingüística de la península ibérica en la Antigüedad. I: Preliminares y mundo meridional prerromano. Madrid: Consejo Superior de Investigaciones Científicas.

De Hoz, J. 2011. Historia lingüistica de la península ibérica en la Antigüedad. II: El mundo ibérico prerromano y la indoeuropeización. Madrid: Consejo Superior de Investigaciones Científicas.

De Hoz, J. 2019. Method and methods: Studying Palaeohispanic languages as a discipline. In Palaeohispanic languages and epigraphies, ed. A.G. Sinner and J. Velaza. Oxford: Oxford University Press.

Díaz Ariño, B., M.J. Estarán, and I. Simón. 2019. Writing, colonization and Latinization in the Iberian Peninsula.
In Palaeohispanic languages and epigraphies, ed. A.G. Sinner and J. Velaza. Oxford: Oxford University Press.

Ferrer, J., and N. Moncunill. 2019. Writing systems. In Palaeohispanic languages and epigraphies, ed. A.G. Sinner and J. Velaza. Oxford: Oxford University Press.

Gorrochategui, J. 1995. Los Pirineos entre Galia e Hispania: las lenguas. Veleia 12: 181-234.

Gorrochategui, J., and J.M. Vallejo. 2019. The parts of Hispania without epigraphy. In Palaeohispanic languages and epigraphies, ed. A.G. Sinner and J. Velaza. Oxford: Oxford University Press.

Luján, E. 2019. Language and writing among the Lusitanians. In Palaeohispanic languages and epigraphies, ed. A.G. Sinner and J. Velaza. Oxford: Oxford University Press.

Moncunill, N., and J. Velaza. 2017. Ibérico. Lengua. Escritura. Epigrafia. Zaragoza: Prensas de la Universidad de Zaragoza.

Ripollès, P.P., and A.G. Sinner. 2019. Coin evidence for ancient Hispanic languages. In Palaeohispanic languages and epigraphies, ed. A.G. Sinner and J. Velaza. Oxford: Oxford University Press.

Untermann, J. 1975-2001. Monumenta linguarum Hispanicarum. Wiesbaden: Reichert.

Vallejo, J.M. 2016. Onomástica paleohispánica. I Antroponimia y teonimia. 1 Testimonios epigráficos latinos, celtibéricos y lusitanos, y referencias literarias. Universidad del pais Vasco. http://hesperia.ucm.es/pre sentacion_onomastica.php

Velaza, J. 2019 . Iberian writing and language. In Palaeohispanic languages and epigraphies, ed. A.G. Sinner and J. Velaza. Oxford: Oxford University Press.

Villar, F. 2000. Indoeuropeos y no indoeuropeos en la Hispania prerromana: las poblaciones y las lenguas prerromanas de Andalucía, Cataluña y Aragón según la información que nos proporciona la toponimia. Salamanca: Ediciones de la Universidad de Salamanca.

Zamora, J.A. 2019. Phoenician epigraphy. In Palaeohispanic languages and epigraphies, ed. A.G. Sinner and J. Velaza. Oxford: Oxford University Press. 